\title{
VISUAL AIDS AS A PART OF SECOND LANGUAGE LEARNING STRATEGIES
}

\section{Assoc. Prof. Dr. Dileta Jatautaitė, Assoc. Prof. Dr. Jelena Kazimianec}

\author{
General Jonas Žemaitis Military Academy of Lithuania
}

\begin{abstract}
The article analyses the notion of implementation of visual aids as a part of second language learning strategies (SLLS). Moreover, the article highlights the implementation of visual aids via multimedia in teaching the second language at the Military Academy of Lithuania (MAL) by applying the questionnaire for English language teachers and learners involved in English language learning and acquisition at the MAL. For this purpose of the research, the diagnostic questions were developed by using validated and reliable questionnaires such as the Revised Study Process Questionnaire (R-SPQ-2F) and the Learner-Teacher Motivation (STM) questionnaire in terms of the implementation of visual aids in the SL learning and acquisition curriculum process. The analysis of the advantages of this method implementation into learning process is presented in the article, as well as the requirements and recommendations for authentic audio-visual materials on the basis of multimedia applied for the realization of pedagogical case study in a regular academic curriculum content and the technology of methodological development of authentic video or audio material for the achievement tests. The objective of the research is presented and described on the basis of the research. The research showed the significance of effectiveness of implementation of visual aids methods into the second language learning for they economize teaching, learning and acquisition time and increase motivation of both teachers and learners necessary to stimulate and boost psychological traits of a learner, such as verbal memory, behavior, positive emotions and others indispensable for participating in the language learning process and acquisition. Thus, the object of the research is based on visual aids as a part of SLLS alleviating and facilitating SL learning and acquisition by implementing visual aids as a part of SL learning strategies.

The aim of the research is to apply visual aids as direct strategy in the language learning process as a part of SLLS used in the acquisition of a SL. Based on the theoretical and methodological SL learning approach of direct and indirect learning strategies, the methods of visual aids were chosen as the best means to accomplish the aim: to achieve the best effect of the SL learning and acquisition via implementing visual aids as a part of the SL learning strategies. In order to conduct the already set objectives of the research and to test the hypotheses of the research, the questionnaire was used to collect the required data. Moreover, besides the questionnaire data, the data of log observation sheets, pull-out focus groups, checklists, achievement tests and surveys of learners were analyzed too.
\end{abstract}

Key words: communicative competence, strategic competence, learning strategies, communicative strategies, visual aids direct strategies, indirect strategies. 


\section{Introduction}

New methods of language teaching methodology are required to deal with any difficulties that the teachers face in teaching the second language (SL) and selecting an appropriate method necessary in the classroom. Nowadays an active quest for new methods, techniques strategies of teaching SL is experiencing new advancements in new technologies by implementing herein multimedia into the language teaching so that to alleviate the learning and acquisition process. Thus, it is very beneficial to apply information technology (IT) into the language teaching and learning process, in this case regarding the Next Generation of Learners or Generation Z (defined as ages 14-23) and Millennials (defined as ages 24-40), who are very technology savvy in IT, to attain proficiency in any foreign tongue in the shortest time. Technology is no longer a transformative phenomena for these generations, but rather a normal, integral part of life (Pearson, 2018). This meets the current state of methodological science and the rapid development of new teaching technologies for the new generation learners as a whole. Intensive computerization of language teaching and learning labs and classrooms is very much in unison proceeding with the SL teaching and learning environment not only in Lithuania but in the whole world. It is very beneficial to apply all these gadgets and devices in developing new learning habits of an individual learner.

Innovative technological perception of a new generation can easily recognize vast Intel spreading from the digital screen which activates the perception and cogitation of visual resources of learning in the system of all types of education: formal, informal and non-formal. In other words, the concept of lifelong learning has become of vital importance with the emergence of new technologies that transform how we receive and gather information, collaborate with others, and communicate. Consequently, contemporary teachers of SL have already obtained a lot of knowledge in IT, so they can successfully work and go on developing and designing new visual aids methods for their learners in the SLL process. In particular, it concerns lifelong learning for it encompasses from the teacher all his/her learning activities undertaken throughout his/her life with the aim of improving individual and professional knowledge, skills and competences necessary for his/her successful career as a teacher. Besides, a modern language teacher needs to develop methodologies of teaching design, quality in education, career design, adult learning, teacher/andragogue training and e-learning to model systems of quality assessment in learning/studies and quality assurance in education building on research results in lifelong learning in all levels of education system (ec.europa.eu).

Moreover, in our modern computerized society the skills demanded from employees are called 21st-century skills, they embrace effective communication, collaboration, cooperation, research, critical-thinking and analyzing skills, as well as skills to effectively develop oneself, to increase learning, knowledge creation, 
innovation, engagement, problem-solving, information retrieval, organization and to comprise lifelong learning (ec.europa.eu).

\section{What are Visual Aids?}

There is a great variety of deducing visual aids but what is obvious about them that they are a powerful interpretation of these instruments as great enhancers on an individual's capability of learning and acquisition of the SL. Words and images presented in different formats appeal directly to learner's imagination by adding power to the teacher's spoken or written words. Accordingly, visual aids implemented in the teaching and learning curriculum by teachers are supposed to better involving opportunities and engaging the learners in much more effective communication activities.

These opportunities for interactions can be provided by computermediated communication (CMC), synchronous (CMC) or asynchronous means of communication (CM). According to Schetzer and Warschauer (2000: 173), this kind of communication is network-based language teaching (NBLT) that consists of e-mail, blogs, discussion forums, wikis, electronic bulletin boards, and chatting with or without sound. In addition, for example, Stempleski (1987) states that "authentic video material designed for its entertainment value rather than language teaching is a rich and exciting source of video software for instruction in English as an ESL". Moreover, Ahmad (2013) mentions several kinds of learning resources that are also considered by him as useful teaching and learning visual aids, such as television programs, video films, motion pictures, synchronized audio-slide projectors, computers and computer-assisted instructions and other belonging to multimedia that also stimulates a faster foreign language communication.

The problem of the research lies in a big necessity for the military in Lithuania and other NATO countries to speak at least a few foreign languages. Moreover, it is significant to intensify the development system of foreign language teaching and learning paradigm in honing second language learning for the reason that the military and other military personnel participate in various military and humanitarian missions. Therefore, every day officers experience various engagements in confronting life-threatening circumstances in hostile environment and foreign language awareness can help 'survive' in these serious situations. Hence, the reasons to learn a foreign language or two for the military have never been stronger. What is more, the military personnel cannot entertain promotion in the army without skillful foreign language knowledge. But on the other side, they are technologically savvy, so they can easier and faster learn foreign languages by being taught with the help of visual or other technological aids. Thus, there is a great problem: how to teach the second foreign language in the shortest means of time and to make our military the most effective and operative in performing their duties. 
The aim of the research is to apply visual aids as a direct strategy in the language learning process as a part of SLLS used in the acquisition of a foreign language taught at the MAL.

The object of the research is the visual aids' implementation effectiveness in the language learning process as a part of SLLS used in the acquisition of SL.

Methods of the research: achievement test to determine the change in SL learning acquisition, questionnaire data, and the data of log observation sheets, pull-out focus groups, checklists, achievement tests and surveys of learners were analyzed and implemented into the research.

\section{The Implementation of Visual Aids in Organizing the SL Learning}

Authentic visual aids tasks are believed to enable learners to explore the target language not only in structure but also in functionality. This approach is described as creating opportunities to psychologically interact with the target language, which means that a learner processes the acquired knowledge in the way that it links and modifies with already existing information (Data-Driven Learning (DDL): the idea by Ruschoff, 1999). According to Burton (1982), "visual aids are those sensory objects or images which initiate or stimulate and support learning". For instance, Kinder S. James (2010) describes visual aids as "any devices which can be used to make the learning experience more real, more accurate and more active".

The spread of computers and Internet has caused noticeable expansion of the use of technology in SL instruction (Levy, Hubbard 2006: 1). Computers and Internet-introduced language teaching tools help teachers to supply learners with more up-to-date, authentic, target-specific, and learner-oriented materials. It was related to the fact that practitioners and theoreticians thought alike; emerging technological applications and tools were the potential for enhancing rather than just assisting language learning and classroom practice (Thomas, 2013: 20).

Moreover, the breakthrough of two cutting-edge technologies, such as computers and Internet in the mid-1990s (Warschauer 1996: 3-20), helped teachers move away from a cognitive view of communicative teaching towards a socially emphasized language use in the authentic social context. All the four language skills, such as listening, reading, writing, and speaking were integrated and the technology was completely adapted to the language learning process. Multimedia is believed to create more authentic learning environment where the language skills could be easily integrated. The Internet enabled the search through enormous number of files from around the world within minutes to find and access materials especially adapted and tailored to the learner's interests. It enabled the learner to use the Web to carry out their written assignments through multimedia and share them later with other course learners.

The purpose of the research was for learners to gain communicative skills in a direct, inexpensive and convenient way (http://opencourses.uoa.gr/courses/ 
ENL10/). According to other scholars of didactics, such as Schetzer and Warschauer (2000: 173), Stempleski (1987), Schmidt-Rinehart (1994), Ahmad (2013), Nunan (1999), Clarke (1989), Bacon \& Finnunan (1989), Miller, Herron and Seay (1991) Mishan (2005), Brown (2006) and many others, who worked in this field, stated that the language of the real world is what learners need to be exposed to because that language is uncompromising towards the learner and reflects real world goals and situations. Therefore, authentic materials need to be well designed and prepared by the teachers for they reflect how the language is used in authentic communication. Moreover, learners need to listen carefully to the instructions and explanations provided by teachers and lecturers in order to comprehend all the information so that they could actively participate in authentic language activities. For example, Brown (2006) asserts that learners with good listening skills have better ability to take part effectively in class because they understand the instructions from their teacher better than the other learners. The application of authentic materials can also enhance the learner's awareness with forms of the language and its use in communications.

Professional language instructors in favor of using authentic materials emphasize the importance of exposure to authentic materials which should be introduced to learners at the earliest stages of language learning; then individuals can develop useful strategies for more complex tasks later on. Similarly, the use of authentic materials reveals the way learners experience real-world language learning materials. The findings of the above-mentioned studies have indicated that authentic materials can be useful in many ways. Such materials introduce learners to how language is used in the real world and improve their overall language proficiency and skills, communicative competence, and lexical and stylistic knowledge. Van Staden (2011) in his research claims that visual aids and multimedia should be used as a platform for learners with different ways in different levels. In their study, Shaw, Baggett, and Salyer (2004) stress that computer technology can be incorporated into the SL learning and acquisition programs to improve learners' motivation. In their recommendations, they state that it is essential to use visual thinking tools for they can extend learners' cogitation operations.

\section{Why Language Learning Strategies are Necessary in the Language Learning and Acquisition Process?}

The methodology of SLLS is essential for the reason that they are centering learning, arranging and planning. According to Oxford (1990), the aim of centering learning is to give a focus to the learner so that the attention could be directed toward certain language activities or skills.

Moreover, Oxford (1990) provides (see Picture 1) the classification of direct learning strategies that are directly involved in the target language learning and acquisition. 
Picture 1. Language learning direct and indirect strategies.

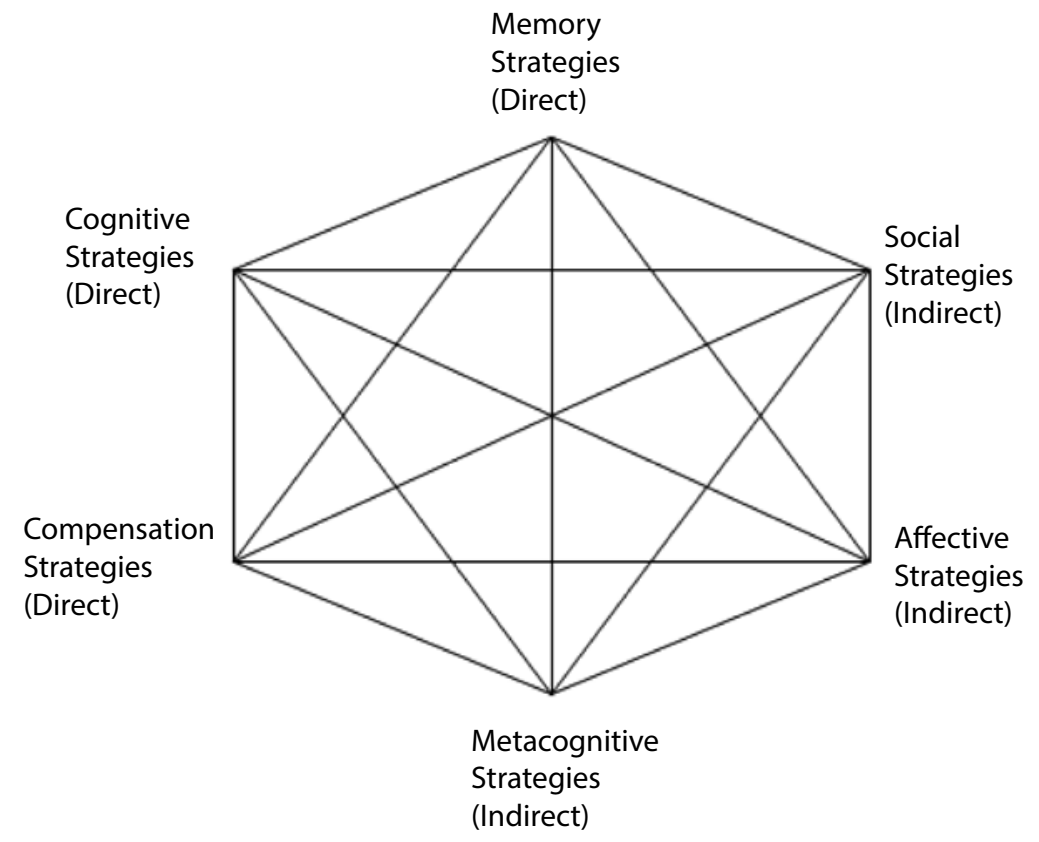

Source: Oxford, Rebecca L. (1990). Language Learning Strategies -

What Every Teacher Should Know, Heinle\&Heinle, Boston, USA

These strategies include memory, cognitive, and compensation strategies. All of these direct strategies involve mental processing of language. As learning strategies are actions developed by learners to make the learning process easier and enjoyable, they are conscious actions chosen by the teacher and play an active role in the learning process. Furthermore, the strategies may affect learning both directly and indirectly; then contribute to the main goal of communicative competence in four language skills. What is essential, visual aids design should be constructed on the basis of direct and indirect knowledge. The indirect strategies are very significant for they involve in metacognitive assets effective and social strategies and provide indirect support for language learning through focusing, planning, evaluating, seeking opportunities, controlling anxiety, increasing cooperation and empathy, and other means in quest of the best teaching and learning strategies.

While designing the research, it was very important for the researchers to integrate visual aids into the learning process by considering direct and indirect strategies defined by Oxford as "operations employed by the learner to aid the acquisition, storage, retrieval, and use of information". This organization also stipulates "specific actions taken by the learner to make learning easier, faster, more enjoyable, more self-directed, more effective, and more transferrable to new situations" (Oxford, 1990, p. 8). These definitions determine the main focus in SL 
teaching and learning on learner-centered instruction by the teacher.

The strategies implemented directly in dealing with a new language are direct strategies which reveal the fact that the teacher cannot construct any model of the learner's language learning and acquisition without considering direct and indirect strategies (see Picture 1). Indirect language learning strategies work together with the direct strategies which are essential in selecting visual aids into the learning process of the SLLA. Hence, they both help the teacher and the learner regulate the learning process. Moreover, visual aids materials, such as multimedia, can have a positive effect on the learners' comprehension of the learning content helping them to overcome learning difficulties through the use of videos, photos, websites, smart boards, and other technologies by alleviating stress and raising motivation.

The review of the scientists, such as Staden (2011), Shaw, Baggett and Salyer (2004), Schetzer and Warschauer (2000: 173), Stempleski (1987), SchmidtRinehart (1994), Ahmad (2013), Nunan (1999), Clarke (1989), Bacon \& Finnunan (1989), Miller, Herron and Seay (1991), Mishan (2005), Brown (2006) and many others in their research claim that visual aids and multimedia should be used as scaffolding for the learners with different ways in different levels. This review of methodology of the scientist working in a new paradigm of language teaching and learning didactics also indicate the extent of facilitating the learning process through the use of multimedia and how multimedia can improve the learner's intellectual and emotional efforts by concentrating and motivating him/her to effectively participate in the classroom.

Furthermore, authentic visual aids motivate learners with their vivid and interesting component and relaxing learning atmosphere, which encourage their interaction and participation in the language learning. Most importantly, compared to a printed course book, authentic visual aids provide "real language" and "an authentic look at the culture" (Stempleski, 1990, p.9) and intertwines Englishlanguage culture and linguistic knowledge, such as "accents, vocabulary, grammar and syntax, and all kinds of discourse" (Sherman, 2003). Furthermore, Nunan (1999) emphasizes the importance of the learners who "should be fed as rich a diet of authentic data as possible". He asserts that if they only ever encounter artificial dialogues and listening texts, their learning tasks will be made more difficult in real life. Therefore, it is important for learners to work on as many as possible original materials so that they learn and hone their four language skills through direct and indirect strategies designed on visual aids.

\section{Methodology and Methods of the Research}

With the changes to the curriculum of the Department of Foreign Languages to a competence-based and process-based learning structure with a learner-centred approach, cadets and military personnel as SL course learners are put in charge of their own development. Based on the theoretical and methodological SL learning 
approach of direct and indirect learning strategies, the methods of visual aids were chosen as the best means to accomplish the aim: to achieve the best effect of the SL learning and acquisition via implementing visual aids as a part of the SL learning strategies. In order to conduct the already set objectives of the research and to test the hypotheses of the research, a questionnaire was used to collect the required data. Moreover, besides a questionnaire data, the data of log observation sheets, pull-out focus groups, checklists, achievement tests and surveys of learners were analyzed too.

This research was properly planned in 2017-2018 period by a team of teachers working at the MAL with the military and civil personnel (60) studying ESL and cadets (37) learning SL at the Department of Foreign Languages and conducted the research with two groups, an experimental group (EG) and a control group (CG). The EG was taught by using authentic visual methods, while the CG executed the curriculum only through conventional audio compact discs (CD) that corresponded the already designed programs as the main teaching aid most often used by the ESL teachers. In collecting the data, the methods of the research, such as log observation sheets, pull-out focus groups, checklists, the achievement test and surveys of learners were applied and analyzed.

The achievement test was designed by the testing methodologists group and the lecturers from the Department of Foreign Languages. In order to conduct the research and to test the hypotheses of the research of how effective, beneficial and motivating the implementation of multimedia or other visual aids can be for the teachers teaching SL and for the individuals learning the SL, the closed ended questionnaire was used to collect the required data. In fact, the learners of the courses were required to sit in the classroom and listen to the prepared material from the teacher and prepare small assignments. They were tested using the achievement test, and had to pass exams at the end of the course or the year.

The structure of the curriculum was similar to the curriculum found in other educational institutions. The key aspects of the new DP curriculum are competencebased, learner-centred and military working-life oriented. While learning the SL, the professional capabilities of the learners were developed throughout the studies, as well as the learner's competences were assessed at the beginning of the studies then provided with feedback and knowledge on the current level of skill improvement. Additionally, it was significant for the research to plan and to develop the necessary but not yet completely developed individuals' abilities as stated by Hattie (2009, 49). What was significant for the research too, it was developing each individual's personal capabilities as 'transparent success criteria' by closely monitoring them by the teacher or lecturer (Hattie 2009, 49). On the other side, during the research, the learner was required to monitor his/her own progress too. In this way, for this particular research, it was important to achieve 'learning visible' for both of the sides involved in the learning process so that to control the progress and finalize the curriculum of the research (Hattie 2009, 49). 
Subsequently, it was very significant for the researchers who kept the study process as learner-centered in EG to determine the central role of an active learner who, through the use of visual aids, intensified and boosted the learning of the SL topics actively and independently and was motivated for deeper learning of the SL.

\section{The Results of the Research}

The experiment aimed to investigate the impact of using visual aids for teaching SL on the basis of the direct and indirect strategies (Oxford, 1990) and was conducted from September 2017 to May 2018 with the cadets, military officers, military personnel and cadets who attended the second language learning courses at the MAL. The methodologists and English teachers were the ones who facilitated organizing, implementing and conducting the research.

The research employed true experimental research methods with two groups, EG and CG. The EG was taught by using authentic visual methods, while the CG used only audio compact discs (CD) according to the programs as the main teaching aid most often used by the ESL teachers. The experiment consisted of the three main parts: 1) independent and dependent variables, 2) pre-testing and post-testing, 3) experimental and control groups. The independent variable, studied in the experiment, was expected to change when the independent variable was changed. So the objective of having a control was to rule out other factors which might influence the results of the controlled experiment.

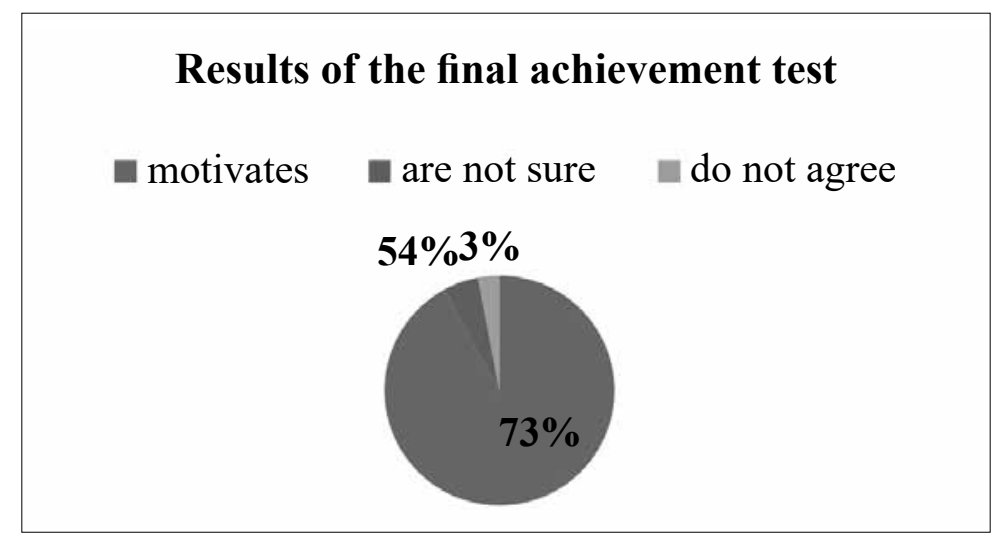

Figure 1. Results of the final achievement test

In collecting the data, the tests were designed and implemented by the testing group methodologists together with the teachers and the lecturers from the Department of Foreign Languages. There were 8 facilitators all together and 97 participants in the research. The score of the results of the final achievement test of the EG was $73 \%$ which was higher than that of the CG at $54 \%$. Moreover, the 
knowledge of the achievement evaluation test was given the same but the score of the EG was higher than that for the CG (19\%) which meant that the improvement in the EG was significantly higher than the achievements of the CG. The EG learners, taught by using authentic visual aids by multimedia, achieved higher results than the CG that was taught by $\mathrm{CD}$ as the only means of authentic material. As a result, the alternative hypothesis was accepted and null hypothesis was rejected which meant that there was a significant improvement in terms of test achievements in all four skills after the use of authentic visual aids in SL teaching and language learning and acquisition of a learner.

From the interview with the learners, it was acknowledged that most of them tried to understand authentic language material but it was quite challenging. In order to cope better with authentic visual aids, they made themselves do extra activities after classes on their own initiative (89\%).

What is important, authentic use of visual aids motivated them for more intensive learning. Meanwhile, in CG, the learners asserted that they did not even have a wish to do more than it was given by the teachers (84\%). Consequently, only $16 \%$ of learners were motivated enough to do an additional attempt in their own learning (see Figure 2).



Figure 2. Motivation of learners and teachers in terms of visual usage.

The collected data is evaluated through the percentage distribution and is presented in the pie chart.

The bar graph shows the percentage distribution between the learners and the teachers who, based on their experience, expressed their opinion in terms of visual aids stimulating their motivation. Moreover, the data analysis shows that $70 \%$ of all learners, who participated in the research, and 92\% teachers, who were involved in the research, agreed that the visual aids are essential in their learning and teaching motivation (see Figure 3). 


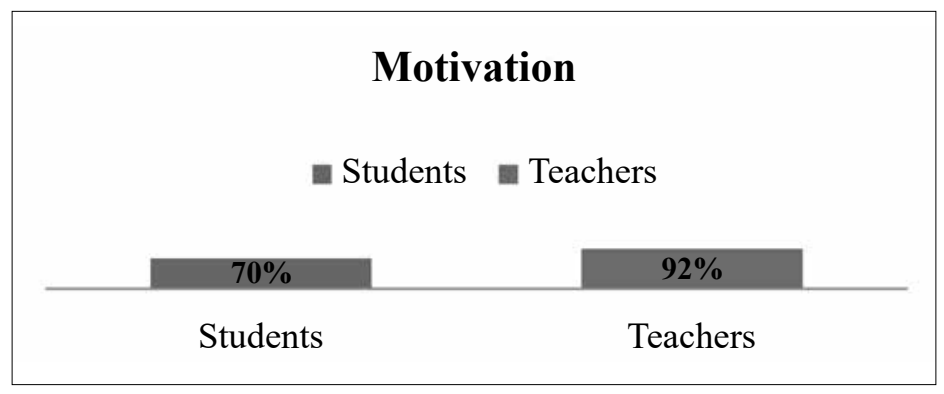

Figure 3. The difference of motivation between the teachers and the learners involved in the research.

What is more, the data analysis (see Figure 4) shows that besides $92 \%$ of teachers, who stated that they were highly motivated by the implementation of visual aids into their teaching material and tools, also mentioned the importance of clarification of the teaching material content but there were $5 \%$ of teachers who doubted about the major influence on their motivation and 3\% totally disagreed with the motivating statement which means that they did not consider visual aids as a motivating factor of their teaching process at all. The bar graph shows the percentage distribution of the teachers participating in the experiment in terms of motivation through the implementation of visual aids into the learning process of the SL.

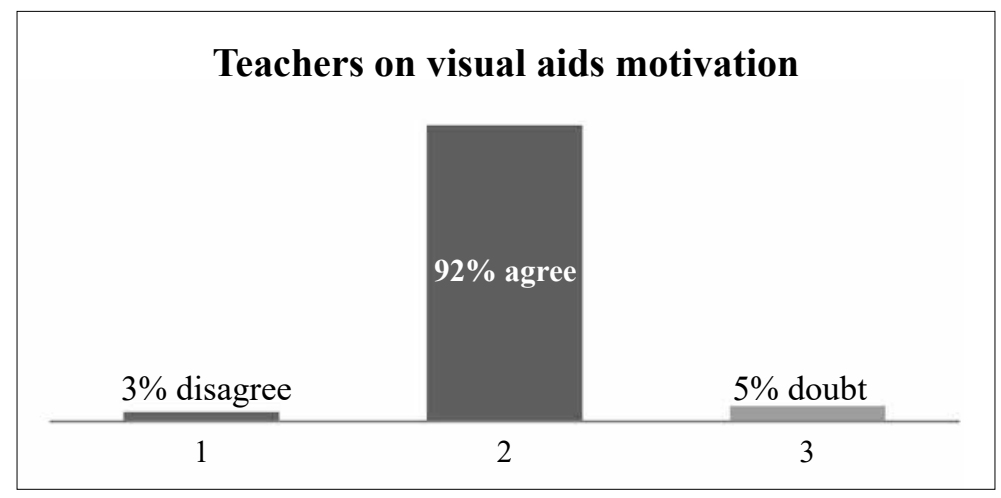

Figure 4. Motivation of the teachers in terms of the use of visual aids.

Furthermore, the results of the R-SPQ2F part shows that learners can be divided into three groups: one with a deep, one with an intermediate and one with a surface approach to learning.

The results of the research also indicate that learners employ a variety of mental activities in their studies as well as improve their personal skills. The data from the MSLQ point out that the level of intrinsic motivation the learners possess is high but self-confidence, the use of cognitive strategies and self-regulation could be improved. 
All in all, the results clearly indicate that the change of the study structure was a step into the right direction but that the process-based and learner-centred approach still is in need of improvement to develop the learners' engagement into the learning process and acquisition, and motivation.

Therefore, the study concluded that the use of visual aids and multimedia can facilitate the language learning and acquisition of the learners to absorb the content of the curriculum and be interactive in the ambient classroom with no fear and frustration but remain highly motivated. Furthermore, the analysis of the data indicated that the majority of the teachers and learners had positive perceptions of the use of visual aids, multimedia and other visual aids or technologies applied in the SL learning and acquisition process.

In conclusion, the achievement test results of the EG were significantly higher than those of the CG. It means that the implementation of authentic visual aids positively influenced the learners' four language skills.

- The data analysis of the test obtained from the EG listening was most enhanced after the application of authentic visual aids.

- All the teachers who facilitated in the research mentioned that using authentic visual aids in the language classroom can be quite challenging for the learners, but it is also more interesting and exciting at the same time.

- The learners in the focus group mentioned the fact that using authentic video brought the content and the subject matter to life for them which they found very beneficial and motivating.

- According to the analysis of the findings and the discussions, using authentic video as an audio visual aid is a successful method for noticeable improvement of listening skills.

- Incorporating authentic materials in teaching a SL offers more than just linguistic advantages. In this regard, the motivating power of authentic materials is a key factor in a successful language learning.

- The data was analyzed statistically to find out whether the hypothesis in this study was accepted. The result confirms that the variance of both groups was $10.41>3.94$ for the EG and 3.06>1.94 for the CG. This shows that both groups performed better in four skill achievement test after the implementation of SLLS. Nevertheless, the result of the t-test for the EG was significantly larger than the $t$-test for the CG $(10.41>3$. 94). Therefore, the improvement was bigger in the EG compared to the CG.

\section{Conclusions and Suggestions}

The achievement test results of the EG were significantly higher than those of the CG which means that the implementation of authentic video positively influenced the learners' four skills in the achievement test.

From the data analysis of the test obtained from the EG, it can be concluded 
that listening for specific information was the most enhanced sub-skill after the application of authentic video as an audio visual aid in the classroom.

The EG obtained the highest score from listening and reading sub-skills:

$\checkmark$ listening and reading improved in search of main ideas,

$\checkmark$ listening and reading for the gist,

$\checkmark$ listening and reading for detailed information,

$\checkmark$ listening and reading for specific information improved more significantly than writing.

$\checkmark$ Hence, writing honed least.

Using authentic video in the language classroom can be quite challenging for the learners, but it is also more interesting at the same time. This could be due to the fact that using authentic video may bring the content and the subject matter to life for them enabling them to make important connections with the world outside the classroom.

According to the analysis of the findings and the discussions with the EG, using authentic video as an audio visual aid was a successful method for improving speaking skills as well:

$\checkmark$ the learners learned a significant number of lexis and

$\checkmark$ improved pronunciation, enunciation, clarity, pace, projection, and other speaking sub-skills.

In addition, the use of visual aids can more effectively help the teachers support and stimulate individual's learning by monitoring and evaluating their performance.

Due to visual aids, the teacher increases the capacity to create an attentiongrabbing and interactive lesson through the use of the computer and other visual aids technologies.

\section{References}

1. Ahmad, T. (2013). Audio-Visual Aids in Teaching. Retrieved December, 12th 2014, from http://www.dailykashmirimages.com/news-audio-visual-aids-inteaching-42083.aspx.

2. Asokhia, M. O. (2009). Improvisation/Teaching Aids: Aid to Effective Teaching of English Language. International Education Science, 1(2), 79-85.

3. Bacon, S. M., \& Finneman, M. D. (1989). A Study of the Attitudes, Motives, and Strategies of University SL Learners and Their Disposition to Authentic Oral and Written Input. The Modern Language Journal, 74(4), 459-473.

4. Barron, B., \& Darling-Hammond, L. (2008). Teaching for Meaningful Learning: A Review of Research on Inquiry-based and Cooperative Learning (PDF). Powerful Learning: What We Know About Teaching for Understanding. San Francisco, CA: Jossey-Bass.

5. Benet, C. (2012). Teaching Listening Strategies with Authentic Videos: 
An Intervention Study with EFL Secondary School Learners in Catalonia. (Unpublished Thesis). Catalonia, University of Barcelona.

6. Berk, R. A. (2009). Multimedia Teaching with Video Clips: TV, Movies, Youtube, and MTV in the College Classroom. International Journal of Technology in Teaching and Learning, 5(1), 1-21.

7. Brown, S. (2006). Teaching Listening. New York: Cambridge University Press.

8. Brown, H. Douglas (1994). Teaching by Principles: An Interactive Approach to Language Pedagogy, Longman, London SLs in the Secondary SchoolA Companion to School Experience, Routledge, London, p. 67

9. Burton, J. K., \& Bruning, R. H. (1982). Interference Effects on the Recall of Pictures, Printed Words, Spoken Words. Contemporary Educational Psychology, 7, 61-69.

10. Burton, J. K. (1982). Dual Coding of Pictorial Stimuli by Children. Journal of Mental Imagery, 6(1), 159-168. Celce-Murcia, M. (1991). Teaching English as a Second or SL. In J. M.Morley, Listening Comprehension in Second SL Instruction. NewYork: Newbury House.

11. Clarke, D. (1989). Communicative Theory and Its Influence on Materials Production. Language Teaching, 22, 73-86.

12. Conroy, P. (1999). Total Physical Response: An Instructional Strategy for Second-Language Learners Who are Visually Impaired. Journal of Visual Impairment \& Blindness, 93(5), 315-318.

13. Cooper, L. Z. (2002). Considerations in Cross-cultural Use of Visual Information with Children for Whom English is a SL. Journal of Visual Literacy, 22(2), 129-142. https://doi.org/10.1080/23796529.2002.11674585

14. Cunningham, J. (1991). Making and Using Slides in the ESL Classroom. TESL Canada Journal, 9(1), 67-78. https://doi.org/10.18806/tesl.v9i1.597

15. Gorman, R., Eastman, G. S. (2010). I See What You Mean: Using Visuals to Teach Metaphoric Thinking in Reading and Writing. English Journal, 92-99.

16. Gilmore, A. (2007). A Comparison of Textbook and Authentic Interactions. ELT Journal, 58(4), 363-374.

17. Hadley, A. (2001). Teaching Language in Context (3rd ed). Boston: Thomson Heinle.

18. Hattie, J. A. C. (2009). Visible Learning: A Synthesis of 800 Metaanalyses Relating to Achievement. Oxon, England: Routledge.

19. Herron, C., Seay, I. (1991). The Effect of Authentic Oral Texts on Learner Listening Comprehension in the SL Classroom. SL Annals, 24(6), 487-495.

20. Kearsley, G. Schneiderman, B. (1999). Engagement Theory: A Framework for Technology-based Learning and Teaching. Originally: http://home. sprynet.com/ gkearsley/engage.htm. Retrieved 14:42, 11 September 2006 (MEST) from google cache.

21. Kinder, S. James (2010). http://avaudiovisualaids.blogspot.com/2010/10/ 
av-aids-in-teaching. html

22. Kilickaya, F. (2004). Authentic Materials and Cultural Content in EFL Classrooms. The Internet TESL Journal, 10(7), 1-6. Retrieved April 7, 2015 fromhttp://Techniques/Kilickaya-AutenticMaterial.html.

23. King, J. (2002). Using DVD Feature Films in the EFL Classroom. Computer Assisted Language Learning, 15(5), 509-523.

24. Kearsley, G. and Shneiderman, B. (1998) Engagement Theory: A Framework for Technology-Based Teaching and Learning. Educational Technology, Sept/Oct pp. 20-37.

25. Miller, M. (2005). Improving Aural Comprehension Skills in EFL, Using Authentic Materials: An Experiment with University Learners in Nagata, Japan. (Unpublished Master's Thesis). Sydney, University of Sydney.

26. Mishan, F. (2005). Designing Authenticity into Language Learning Materials. Intellect Books.

27. Nunan, D. (1999). Practical English Language Teaching (1st Ed). Singapore: McGraw-Hill.

28. Schwalm \& Smuck Tylek (2012). Afterschool Matters, n15 p1-8 Spr Schmidt-Rinehart, B. C. (1994). The Effects of Topic Familiarity on SL Listening Comprehension. The Modern Language Journal, 78, 179-189.

29. Sherman, J. (2003). Using Authentic Video in the Language Classroom. Cambridge: Cambridge University Press.

30. Stempleski, S. (1987). Short Takes: Using Authentic Video in the English Class.

31. Stempleski, S., Tomalin, B. (1995). Video in Action: Recipes for Using Video in Language Teaching. Prentice Hall.

32. Mohr, K. A. (2004). English as an Accelerated Language: A Call to Action for Reading Teachers. The ReadingTeacher, 58(1), 18-26. https://doi.org/10.1598/ RT.58.1.2

33. Park, C. C. (2000). Learning Style Preferences of Southeast Asian Learners. Urban Education, 35(3), 245-268. https://doi.org/10.1177/0042085900353002

34. Pearson (2018). Beyond Millennials: The Next Generation of Learners Global Research \& Insights August 2018. https:/www.pearson.com/content/dam/ one-dot-com/one-dot-com/global/Files/news/news-annoucements/2018/The-NextGeneration-of-Learners_final.pdf

35. Rüschoff, B. (1999). Construction of Knowledge as the Basis for Foreign Language Learning. In Mißler, B. \& Multhaup, U. The Construction of Knowledge, Learner Autonomy and Related Issues in Foreign Language Learning: Essays in Honour of Dieter Wolff. Tübingen: Stauffenberg.

36. Rüschoff, B. (1999). Wissenskonstruktion als Grundlage fremdsprachlichen Lernens. Fremdsprachen Lehren und Lernen (28), 32-43.

37. Rüschoff, B. \& Wolff, D. (1999): Fremdsprachenlernen in der Wissensgesellschaft: Zum Einsatz der Neen Technologien in Schule und Unterricht. 
München:Hueber.

38. Shaw, E. L., Baggett, P. V., \& Salyer, B. (2004). Kidspintion ${ }^{\circledR}$ for InquiryCentered Activities. ScienceActivities: Classroom Projects and Curriculum Ideas, 41(1), 3-8. https://doi.org/10.3200/sats.41.1.3-8

39. Schwalm J., Smuck T. (2012). System-wide Implementation of Projectbased Learning: The Philadelphia Approach. Afterschool Matters, n15 p1-8 Spr.

40. Shetzer, H., \& Warschauer, M. (2000). An Electronic Literacy Approach to Network-based Language Teaching. In M. Warschauer \& R. Kern (Eds.), Network-based language teaching: C.

41. Sherman, J. (2003). Using Authentic Video in the Language Classroom. Cambridge University Press.

42. Schmidt-Rinehart, Barbara C. (1994). The Effect of Topic Familiarity on Second Language Listening Comprehension. Modern Language Journal, 78(2), 190-89.

43. Thomas, M. Reinder, H. (2013). Task-based Language Learning and Teaching with Technology. Edited by Michael Thomas and Hayo Reinders. ISBN-10: 9781441124012

44. Turner, C. E., \& Upshur, J. A. (1995). Some Effects of Task Type on the Relation between Communicative Effectiveness and Grammatical Accuracy in Intensive ESL Classes. TESL Canada Journal, 12(2), 18-31. https://doi. org/10.18806/tesl.v12i2.650 https://doi.org/10.1515/iral.2004.012

45. Van Staden, A. (2011). Put Reading First: Positive Effects of Direct Instruction and Scaffolding for ESL Learners Struggling with Reading. Perspectives in Education, 29(4), 10-21.

46. Oxford, Rebecca L. (1990). Language Learning Strategies - What Every Teacher Should Know, Heinle\&Heinle, Boston, USA.

47. Warschauer, M. (1996). Computer-assisted Language Learning. An Introduction. In S. Fotos (Ed.), Multimedia Language Teaching. Tokyo Logos International.

48. Underwood, M. (1989). Teaching Listening. New York: Longman.

49. https://ec.europa.eu/education/education-in-the-eu/council-recommendation-on-key-competences-for-lifelong-learning_en 


\title{
VAIZDINIŲ PRIEMONIŲ, KAIP ANTROSIOS KALBOS MOKYMI(SI) STRATEGIJŲ, DALIS
}

\author{
Doc. dr. Dileta Jatautaitė, doc. dr. Jelena Kazimianec
}

Generolo Jono Žemaičio Lietuvos karo akademija

\section{Santrauka}

Straipsnyje analizuojamas vaizdinių priemonių, kaip antrosios kalbų mokymosi strategijų, taikymas užsienio mokymo(si) procese. Straipsnyje pateikta tyrimo problema, tyrimo objektas ir tikslas. Tyrimo tikslas - panaudoti vaizdines priemones, adaptuotas prie mokymo proceso programos ir didaktinès medžiagos turinio, kurios pagreitintų antrosios kalbos mokymą bei išmokimą. Tyrimo metodai ir metodologija remiasi tiesioginio ir netiesioginio mokymosi strategijų teoriniu pagrindu. Vizualinès pagalbos metodas buvo pasirinktas kaip geriausia priemoné besimokančiujjų ir dèstytojų motyvacijai skatinti, t. y. pasiekti veiksmingiausią antrosios kalbos mokymosi ir išmokimo būdą per vaizdines priemones tiesioginių ir netiesioginių strategijų kontekste.

Tyrimo objektas - vaizdinių priemonių efektyvumas kaip dalis antros kalbos mokymo(si) strategijų. Tyrimo tikslas - patikrinti, ar naudojant vaizdines priemones galima pagreitinti antrosios kalbos mokymą(si) bei išmokimą tiesioginių ir netiesioginių strategijų kontekste bei motyvuoti mokymuisi ne tik besimokančiuosius kalbos, bet ir desstytojus. Siekiant igyvendinti tyrimo tikslus, buvo parengtas pasiekimų testas, pritaikyta anketa anglų kalbos dėstytojams, kariūnams bei klausytojams, kurie 2017-2018 metais mokèsi anglų kalbos Lietuvos karo akademijoje. Šiuo tikslu buvo parengtas R-SPQ-2F, besimokančiojo antrosios kalbos ir dėstytojo motyvacijos (SMM) klausimynas, kad galima būtų nustatyti vaizdinių priemonių, naudojamų užsienio kalbos mokymosi procese, efektyvumą. Straipsnyje pateikiami šio metodo taikymo rezultatai, taip pat eksperimentinèje grupeje iškilę mokymo(si) procese probleminiai klausimai. Straipsnyje analizuojami tyrimo metu gauti Pasiekimo testo rezultatai, taip pat straipsnio autorès pateikia rekomendacijų po autentiškos garso ir vaizdo medžiagos ir multimedijos naudojimo eksperimentinejje ir kontrolinèje grupèse, aprašyti kiti su tyrimu susiję duomenys.

Raktiniai žodžiai: komunikacinè kompetencija, strateginė kompetencija, mokymosi strategijos, komunikacinè strategija, vaizdinès priemonès, tiesioginès strategijos, netiesioginès strategijos 


\section{AUTORIŲ LYDRAŠTIS}

Autoriaus vardas, pavardè: Dileta Jatautaitè

Mokslo laipsnis ir vardas: socialinių mokslų daktarè, docentė

Darbo vieta ir pareigos: Generolo Jono Žemaičio Lietuvos karo akademijos Humanitarinių mokslų katedros docentė

Autoriaus mokslinių interesų sritys: psicholingvistika, glotoedukologija, edukologija, tradiciniai ir netradiciniai kalbų mokymo metodai bei metodologija, psichoedukologiniai kalbų mokymo bei išmokimo pagrindai

Telefonas ir el. pašto adresas: (8 5) 210 3560; dileta.jatautaite@mil.lt

Autoriaus vardas, pavardė: Jelena Kazimianec

Mokslo laipsnis ir vardas: humanitarinių mokslų daktarè, docentė

Darbo vieta ir pareigos: Generolo Jono Žemaičio Lietuvos karo akademijos Humanitarinių mokslų katedros docentè

Autoriaus mokslinių interesų sritys: dabartinè rusų kalba, rusų kalbos gramatika, lingvokultūrologija, svetimų kalbų dèstymo didaktika, sociolingvistika, komparatyvistinè lingvistika

Telefonas ir el. pašto adresas: + 37068759 272; jelena.kazimianec@lka.lt

\section{AUTHORS' COVER LETTER}

Author's name and surname: Dileta Jatautaitè

Academic degree and name: Associate Professor, Doctor

Workplace and position: Department of Humanities, General Jonas Žemaitis Military Academy of Lithuania

Author's research interests: psycholinguistics, gloto-educology, neurolinguistics, traditional and non-traditional language teaching methods and methodology, psycho-educational basis in language learning and acquisition

Telephone and e-mail address: +370 5210 3560; dileta.jatautaite@mil.lt

Author's name and surname: Jelena Kazimianec

Academic degree and name: Associate Professor, Doctor

Workplace and position: Department of Humanities, General Jonas Žemaitis Military Academy of Lithuania

Author's research interests: modern Russian, Russian grammar, comparative linguistics, foreign language teaching methods, social linguistics, lingua-culturology

Telephone and e-mail address: +370 68759 272; jelena.kazimianec@lka.lt 